University of Nebraska - Lincoln

DigitalCommons@University of Nebraska - Lincoln

Space, Cyber, and Telecommunications Law

Program Faculty Publications

Law, College of

2002

\title{
Ukrainian National Space Law from an International Perspective
}

Frans G. von der Dunk

University of Nebraska - Lincoln, fvonderdunk2@unl.edu

Sergei A. Negoda

International Center for Space Law, negoda@ukrpack.net

Follow this and additional works at: https://digitalcommons.unl.edu/spacelaw

Part of the Air and Space Law Commons

von der Dunk, Frans G. and Negoda, Sergei A., "Ukrainian National Space Law from an International Perspective" (2002). Space, Cyber, and Telecommunications Law Program Faculty Publications. 55. https://digitalcommons.unl.edu/spacelaw/55

This Article is brought to you for free and open access by the Law, College of at DigitalCommons@University of Nebraska - Lincoln. It has been accepted for inclusion in Space, Cyber, and Telecommunications Law Program Faculty Publications by an authorized administrator of DigitalCommons@University of Nebraska - Lincoln. 


\title{
Ukrainian National Space Law from an International Perspective
}

\author{
Frans G. von der Dunk \\ University of Nebraska-Lincoln, Lincoln, Nebraska, U.S.; fvonderdunk2@unl.edu \\ Former affiliation: Leiden University, International Institute of Air and Space Law, Leiden, Netherlands \\ Sergei A. Negoda \\ Strategic Planning \& Development, International Center for Space Law, Ukraine; negoda@ukrpack.net
}

\begin{abstract}
As one of the three former Soviet republics engaged in space activities, the Ukraine has had to formulate new national space legislation as a means of demonstrating a responsible attitude to the international security system, of harmonizing its legislation with that of its international political and economic partners and of creating clear guidelines for investors. This article presents the background to the formation of Ukrainian space law, describes some of the new laws enacted and discusses these within the context of international space law. Particular attention is paid to the legal regulation of commercial activities, to dual-use issues and to the effect of international cooperation on Ukrainian space law development.
\end{abstract}

\section{Introduction}

Nowadays, the existence of national legislation that directly or indirectly regulates national space activities - and in particular such activities undertaken by private enterprise - is no longer merely a phenomenon, but a reality of space law. There is no common opinion among scientists about the essence of the term "national space law." According to the definition provided by Zhukov (Russia), "national space law is the set of national laws and other regulations which regulate relations of subjects of a national law, appearing in connection to exploration and use of outer space" [1]. This is a rather wide definition. By contrast, when Prof. Cheng (U.K.) pointed out that "... speaking of the world as a whole ... domestic space laws are still at a very early stage of growth, although in time they will no doubt expand rapidly and extensively, particularly among those States with space capabilities" [2], he probably has in mind a more narrow definition, aiming at national laws exclusively or at least predominantly aimed at space activities. For the purpose of analysis, it is proposed to take the second, narrower definition of national space legislation as a point of departure when discussing the place of Ukrainian national space legislation within the international legal environment.

Either way, scientists and practitioners increasingly have to pay attention both to the content of the national space legislation and to the paths for its development.
Apart from obvious relevance at a national level, the content of national space legislation is important both for international lawmakers and for the whole international community. The legal regulations of national space legislation have to correspond to international space law requirements. Also, it would be desirable if the various legal regulations indicated above can be harmonized as closely as possible. Both these features are especially important for the future of international cooperation in the field of peaceful exploration and use of outer space.

It is of special interest to scientists and practitioners to study the national space legislation of the states which were formed after the disintegration of the U.S.S.R. and which inherited its space capabilities. First, these countries have become important actors within the international security system because of their possession of space technologies. Second, space industries of these states represent interesting opportunities for potential international investors - both for states and private entities.

For this reason, we draw the reader's attention to the summary analysis of national space legislation of Ukraine below. It is important to see how it corresponds to the requirements of international space law. Also, we would like to briefly investigate how the Ukrainian national law can be implemented, for example in case a foreign investor intends to invest into the Ukrainian space sector. 


\section{International space law and the formation of na- tional space law}

Any national space law-certainly if the narrower definition of law exclusively or predominantly aimed at space activities is adhered to - is essentially linked to international space law by means of three fundamental provisions in the 1967 Outer Space Treaty, two of which have been elaborated somewhat further already in later space law conventions.

First, there is Article VI which, itself elaborating the general international concept of state responsibility, provides for state responsibility for "national activities in outer space." It is thus clear that states are held responsible to other states for any activities impinging upon the rights of those other states, i.e. violating applicable material rules and obligations under international space law. This applies expressly also to activities undertaken by "non-governmental Entities," in respect of which it is further specified that such activities have to be authorized and supervised on a continuous basis. Obviously, national space law is a means to do exactly that.

Further analysis as to what exactly would constitute "national activities" of a particular state, or activities "in" outer space as opposed to, for example, activities directed at outer space, reveals that there is no communis opinio on this. Far from it: legal experts hold their own different views on the issue, and in the absence moreover of clear authoritative guidance on the international level, those states which felt the need to establish national space legislation knowingly or unknowingly applied their own views - and had the right to do so.

Thus, for example, the U.K. made its 1986 Outer Space Act applicable to activities undertaken by nationals only, irrespective of their place of operation; the Swedish Act on Space Activities of 1982 was applied to space activities undertaken either by Swedish national (including legal entities) or from Swedish soil, and the Russian Law on Space Activities of 1993 took an even wider view when encompassing all activities falling within Russian jurisdiction in its purview.

From the perspective of a particular state implementing international space law through national space legislation, the long and the short of this is that one should at least deal with both space activities undertaken by one's nationals and space activities undertaken from one's territory in order not to be held responsible at the international level without any legal means to cover such responsibilities.

Second, Article VII of the Outer Space Treaty, as elaborated by the Liability Convention of 1972, provides for liability of a state or several states jointly for damage caused as a consequence of space activities, more exactly: as caused by a space object. The state(s) to be held liable have been determined through the fourfold criterion of the "launching state," but the cen- tral point here is that such liability applies irrespective of whether the actual owner or operator of the launch vehicle or its payload is a state itself or, for example, a private entity.

In other words, this liability for damage even if caused by fully private space activities, which at the international level lies with the state(s) qualifying as launching state(s), in turn points to the desirability for such states to cover such liabilities to the extent desired, by means for example of derogation, reimbursement and/or insurance provisions. And here, obviously, national space legislation presents possibly the most comprehensive and effective means to achieve just that.

It may be noted here that even the seemingly detailed definition of the "launching state" leaves major issues unresolved. As a consequence, the Legal Subcommittee of the United Nations Committee on the Peaceful Uses of Outer Space (COPUOS) is currently discussing clarifications and interpretations of this terminology. For example, does the reference to "procurement" by a state of a launch (as one of the criteria to qualify as a launching state) include a licence being given by that state to a private company undertaking the launch? Or, if the use of a "facility" "of a state" for a particular launch leads to that state being a liable party for damage caused by the space object thus launched, what if the launch facility is registered as such in Liberia yet privately owned by an international consortium consisting of (partly) private U.S., Norwegian, Ukrainian and Russian companies, if that same international consortium is registered in the Grand Cayman Islands (i.e. within U.K. jurisdiction), if launches take place from outside territorial waters, and if the U.S.A. has required a license under its national launch act-as is the case with Sea Launch?

Third, Article VIII of the Outer Space Treaty (further elaborated by the 1975 Registration Convention) is of importance for the establishment of national space legislation. Under its provisions, ownership of a space object is not affected by its presence in outer space. More importantly, registration of a space object offers the registration state the right to (continue to) exercise jurisdiction and control over the space object and all personnel thereof. There is probably no better way of giving this provision hands and feet than by means of the establishment of national space legislation; Article VIII thus seems - at least - to urge states to provide for a registration mechanism in the context of their national space legislation, and to assure that jurisdiction and control over the space objects concerned can actually be effectuated.

In sum, international space law, notably of course the Outer Space Treaty and three of its key Articles, do provide a number of comprehensive and overriding reasons and parameters for establishing national space legislation. Nevertheless, much leeway still exists as to the actual implementation by means of national legislation, 
as a consequence of major uncertainties and lack of clarity at the international level. We shall now turn to how the specific Ukrainian case fits into this international picture.

\section{Background to the formation of Ukrainian space law}

Practical space activities started in Ukraine in 1951 when a plant for ballistic missile production was established in Dniepropetrovsk (nowadays called the Production Association "Yuzhmash"). The first orders to the plant concerned the serial production of the missiles p-1 (SS-1), p-2 (SS-2) and p-5M (SS-3). During the 1960s and 1970s a number of further plants, enterprises and research institutes was established in the Ukraine, which took part in the space programs of the U.S.S.R.. The Ukrainian segment of the space industry of the U.S.S.R. was one of its most important components.

Since 1991 Ukrainian enterprises had completed the orders for production of 62 launch vehicles and some satellites. Ukrainian enterprises are actively involved in numerous international projects with partners from Brazil, China, the Russian Federation and the U.S.A.. Examples of Ukraine's first-rate space projects include the manufacture and modernization of the launch vehicles "Zenit," "Cyclone," "Dnepr" known world-wide. There are about 100,000 employees involved in the Ukrainian space sector.

Since 1991 - the year of independence-Ukraine has made a consistent effort to join the community of democratic and economically developed states. This aspiration requires it to undertake a number of measures aimed to perfect its national legislation - in very general terms. Primarily it is necessary to establish a legal framework for the development of democracy, to set-up civilized standards in economic management, and to create a favorable investment climate. Also, it is important to join the basic international treaties in the various fields and to implement them into the national legislation.

The law-making process in the Ukraine was influenced by two main needs:

(1) the urgent necessity to establish the basis for Ukraine's own national legislation; and

(2) the need to implement international treaties and to harmonize national legislation with the legislative systems of the European Union, the U.S.A. and other states which are political and economic partners of the Ukraine.

Before its independence, as a Republic of the U.S.S.R., the Ukraine was mainly subject to the regimes provided by all-union law. Separate, 'national' legislation was almost absent in the Ukraine. The few Ukrainian laws and normative acts were used for regulation of specific internal matters. The circle of such matters was quite narrow since most of the Republic's activities fell within the jurisdiction of the central governmental bodies of the U.S.S.R.. For instance, the Law of the U.S.S.R. No. 1457-I from 1990 "On Sharing of Powers Between the Union of the SSR and the Subjects of the Federation" provided in Article 6, clause 9, that "to the exceptional jurisdiction of the U.S.S.R. in person of its public authorities belongs ... management of space research."

Space legislation was developing in even more complicated conditions. At first, in the legal system of the U.S.S.R. direct regulations related to exploration and use of outer space were absent. This happened because, during the Cold War, all space activities, even those of a civil nature, were mainly controlled by the military authorities. In the interests of national security the space industry was placed in a 'strictly confidential' category. That is why in the U.S.S.R. space activities were regulated by secret decrees, orders, ministerial instructions, and by resolutions of the Central Committee of the Communist Party and the Council of Ministers. Only shortly before the disintegration of the U.S.S.R. the process of establishment of civil space legislation was initiated. But these plans were not fulfillled because of the disintegration of the U.S.S.R..

Just three out of 15 former Soviet republics inherited the U.S.S.R.'s space potential - the Republic of Kazakhstan, the Russian Federation and the Ukraine. All these newly established states have developed their space-related regulations under difficult conditions of economic reforms and reorganization of the space industry from a military to a civil sector of the economy. This process has already been completed fairly successfully in the Russian Federation and Ukraine, whereas Kazakhstan is still developing the basics of its national space legislation.

\section{The Ukraine and international space law}

The Ukraine has decided to include within the concept of national space legislation those laws and regulations which directly regulate space activities and operations of the space industry. At present, this concerns the following number of laws and regulations: five Laws of the Ukraine and parliamentary resolutions, more than 15 presidential decrees, about 20 governmental decrees and a number of international agreements.Furthermore, a number of legal regulations related to telecommunications, entrepreneurial activities, etc. are also used in the regulation of the space industry's operations [3]. ${ }^{1}$

\footnotetext{
${ }^{1}$ All the texts of the Ukrainian space-related laws and regulations discussed in this article can be found in Space Legislation of the Ukraine.
} 
The Constitution of the Ukraine is the main source for the legal regulation of national space activities, international cooperation and the fulfillment of international obligations. In Part IV, Article 92, of the Ukrainian Constitution it is established that development of outer space, international affairs and external economic links are to be regulated by the laws of the Ukraine. The Ukrainian Constitution also provides that international treaties become part of Ukrainian national legislation after the Parliament approves them. Those provisions of the Constitution are strictly related to the international space agreements of Ukraine.

States' Constitutions are also very important sources from an international law perspective, since they formulate the basics for the fulfillment of international obligations. In accordance with practical needs states can issue legal regulations, which work out in detail the Constitution's provisions [4]. For instance, the Law of the Ukraine "On International Agreements of the Ukraine" from 1994 gives concrete expression to the abovementioned Article 92 of the Constitution by providing that "international agreements of the Ukraine, which are concluded and duly ratified, become part and parcel of the Ukrainian national legislation and apply in procedures established for national legal regulations."

As of the time of writing, Ukraine and its governmental bodies have concluded 32 treaties and agreements that directly or indirectly relate to international cooperation in the field of peaceful exploration and use of outer space. From the overall above-mentioned number of treaties and agreements seven were concluded in the framework of the Commonwealth of Independent States (CIS), 14 with the Russian Federation, four with the U.S.A., four with Brazil, Israel, Kazakhstan and China, and three with international organizations.

The Ukraine has ratified the Outer Space Treaty, the Rescue Agreement, the Liability Convention, the Registration Convention, and had joined the consensus regarding the Principles Governing the Use by States of Artificial Earth Satellites for International Direct Television Broadcasting. All these international documents are imposing certain obligations on the Ukraine which it must fulfill - and the first step in this regard might be the implementation of international treaties and their provisions into Ukrainian national legislation.

The Law of the Ukraine "On Space Activities" of 1996 (Law of 1996) is a colorful example of legal regulations which are adopted for the regulation of national activities in accordance with international obligations [5].

Article 17 of the Law of 1996 should be mentioned as the most important clause. This Article states that the Ukraine is subject to international space law, and performs its space activities on the basis of equal rights with other states subject to its own national interests. This law emphasises that the Ukraine must provide for the fulfillment of international obligations in the field of space activities and is responsible in accordance with universally recognized principles of international law and provisions of international agreements to which the Ukraine is a party.

Of course, this refers back inter alia to such key provisions of the Outer Space Treaty as Articles VI and Article VII, as dealt with before. However, also such prominent substantive provisions regarding the peaceful use of the Moon and other celestial bodies and the deployment of weapons of mass-destruction in outer space (Article IV of the Outer Space Treaty), the duties to inform and consult on potentially hazardous activities (Article IX of the Outer Space Treaty) and the duties to assist astronauts in emergency cases (Article V of the Outer Space Treaty and several clauses of the 1968 Rescue Agreement) also merit special mention here. Finally, Article 18 stipulates that the Ukraine should realize its international space activities by supporting and developing international connections.

In order to fulfill the requirements of Articles III and IV of the Outer Space Treaty, Article 9 of the Law of 1996 fixes a list of prohibitions, which must be considered when performing space activities in the Ukraine. Among others, the following are expressly forbidden:

- injection into orbit or an orbital slot of nuclear weapons and all other kinds of weapons of mass destruction by any means and testing such weapons in space;

- using space technologies to affect the space environment for military and other reasons to make it unsafe for human purposes;

- using the Moon and other celestial bodies for any military purposes.

As discussed above, Article VI of the Outer Space Treaty is one of the most important provisions in the international space law system. Like other states, the Ukraine established its regime of state regulation of space activities in order to faithfully reflect the requirements of Article VI of the Outer Space Treaty. Another reason for the use of state control is to safeguard certain national security considerations and prevent the unauthorized transfer of space technologies which can be used for military purposes. The principle of state regulation is the basis for national control of space activities. It is enshrined in Article 4 of the Law of 1996.

The legislative establishment of basic principles, regulations and rules for space activities is one of the main ways by which state regulation is implemented. Equally in the framework of the legal mechanism of state regulation the development of state policy in the field of peaceful exploration and use of outer space and the application of a licensing regime and other procedures are being undertaken. 
The National Space Agency of the Ukraine (NSAU) is the central governmental body, responsible for implementing the state's policy in the field of space activities. The NSAU was established in 1992 according to Presidential Decree No. 117. It has, most prominently, under Article 10, the authority to administer licenses, subject to further elaboration of the activities which may be licensed in the first place and of the procedures of licensing, to be developed by the Government.

As indicated above, both licensing and certification are important components of the state's regulation of space activities, especially when it comes to private entities - both domestic and foreign. The basis for licensing is established by Article 10 of the Law of 1996. Any subject willing to provide space activities in the Ukraine or-if outside the Ukraine-under its jurisdiction, must obtain a licence from the NSAU: in other words, all activities undertaken from Ukrainian territory or by Ukrainian nationals, and probably also those undertaken with Ukrainian-registered spacecraft (because of Article VIII of the Outer Space Treaty). This represents a fairly wide interpretation of "national activities" as targeted by Article VI, and hence a fairly comprehensive acceptance of responsibility. Also, the liability of international space law is quite well covered by these provisions, allowing for legal control over space activities possibly leading to claims for compensation against the Ukraine. Apart from the Law of 1996, provisions regarding the necessity of space activities licensing arise from the Laws "On Entrepreneurial Activities" of 1991 and "On Licensing of Certain Types of Commercial Activities" of 2000.

The institution of certification of space activities and, in particular, of the objects involved is established by Article 12 of the Law of 1996. In order to realize the requirements of Article 12, the Government issued the Space Equipment Certification Rules.

For fulfillment of the Registration Convention's requirements the basics for space activities objects registration are established by Article 13 of the Law of 1996. In particular, objects of space activities are subject to compulsory registration in the State register of space activities objects. The government adopted the rules for space activities objects registration. It is particularly noted in this Article that the Ukraine does not recognize all records made previously in the registers of other countries for an object, after the records of that object have been made in the Register of the Ukraine. If the space activities object is developing jointly with foreign juridical bodies or international organizations, provisions of concluded international agreements (contracts) will apply.

Part V of the Law of 1996 provides the basics for the maintenance of public safety during the performance of space activities. In particular, this concerns issues of en- vironmental security, space equipment transportation and notification of accidents.

In accordance with the Liability Convention's requirements, Article 25 of the Law of 1996 provides that liability for damage caused during space activities is regulated by legislation of the Ukraine. Ukrainian laws will also apply to issues of settlement of disputes arising from such damage. The jurisdiction of foreign law may be applied for dispute settlement if such a condition would be provided by an international agreement or contract.

Finally, Article 24 provides for the future arrangement of obligations for licensees to insure their activities, in order to actually give substance to any reimbursement obligation to be included in future licenses. It may also be noted here that Article 25 delegates the issue of whether any limit would be imposed upon the possibility for the Ukrainian Government to be reimbursed by a licensee in appropriate cases to future legislation.

As we can see from the above, the fulfillment of international obligations in the Ukrainian space law system is provided for in a rather broad manner, awaiting more detailed elaboration whenever that turns out to be necessary.

\section{International cooperation and its influence on Ukrainian space law development}

One more aspect, which has and continues to have a significant influence on the development of Ukrainian space legislation is the participation of Ukrainian entities in international space projects. The need to join certain international treaties and to modify internal legislation appeared in the light of Ukrainian involvement in international cooperation on peaceful exploration and use of outer space.

The Ukraine signed two important international agreements in order for its space entities to be able to perform activities in accordance with the rules and standards adopted in the international space community. By becoming in 1998 a full member of the Missile Technology Control Regime (MTCR), the Ukraine facilitated activities of its space entities in the framework of international space projects. For the purpose of fulfillling MTCR membership requirements, in 1995 the Government of Ukraine enacted the Decree No. 563 “On Approval of Regulations on the Procedure of State Control Over International Transfer of Technologies, which are Used or can be Used for Mass Destruction Arms Development."

The second agreement, which defines the principles of the involvement of Ukrainian space entities in international co-operative projects, is the Agreement between the Government of the United States of America 
and the Government of the Ukraine concerning international trade in the commercial space launch services of 1996. In this Agreement three important rules were established. (1) The governments of States-parties agreed to avoid practices which might create competition between commercial launch providers. They agreed to do this by prohibiting the issuing of grants, loans and subsidies which could disfigure the cost of production or exploitation expenditures on space commercial launches systems. Granting borrowing support to international customers of international commercial launches was also forbidden. The Parties finally agreed not to propose additional services (insurance or guarantees for a second launch), if such services would differ significantly from those established in the international market. (2) The Ukraine was obliged to perform no more than 24 commercial launches a year (this condition was imposed in order to preserve a balance in the international commercial launch services market after the entry of Ukrainian launch-vehicles). (3) The Ukraine must market commercial launch services at prices in accordance with the standards adopted in the market economy countries. This Agreement has successfully performed its functions, and by now has lost its validity.

It is especially interesting for the scope of our analysis to review how the Ukraine modified its national legislation because of the need to participate in such international space projects. First in this connection the "Sea Launch" project, briefly discussed above, must be mentioned. The Sea Launch Company was looking for a loan from a financial consortium in order to cover the expense of buying equipment from the Russian and Ukrainian contractors. The loan's main condition was a guarantee against political risk in the Ukraine for the financial consortium. The International Bank for Reconstruction and Development (IBRD) presented such a guarantee. The Government of the Ukraine concluded with the Sea Launch Company the Project Support Agreement (PSA). Ukrainian obligations according to the PSA were supported by the corresponding IBRD guarantee [6].

For the purpose of participating in the "Sea Launch" project Ukraine not only modified its legislation, but also in 1995 concluded an intergovernmental agreement with the Russian Federation (its company was one of the project's founders) on the procedure of application of Sea Launch Ltd.'s exclusive rights for use of the "Zenit" launch vehicle. Parties to the Agreement-the NSAU and the Russian Space Agency (RSA)-confirmed that Sea Launch Ltd. would have exclusive rights to the launch vehicle "Zenit" after the project became operational. However, exclusive rights for launches from the space complex "Baikonur" will only apply if Sea Launch Ltd provides a certain yearly quantity of commercial launches, which must be defined by additional special agreement between RSA, NSAU and Sea Launch Ltd.

Another typical example of Ukrainian space law modifications concerns the development of the "Globalstar" telecommunications system on the territory of the Ukraine. For the purposes of realization of the "Globalstar" project in the Ukraine the joint venture "Elsacom Ukraine" was established. It was formed by the Central-Eastern European "Globalstar" service provider "Elsacom" (Italy) and by two Ukrainian companies "Ukrtelecom" and "Yuzhmash." The main obstacle to "Globalstar" services in the Ukraine was the prohibition by the Law "On Communications" of 1995 on the management of communications systems (including satellite) by non-governmental entities.

After some hard negotiations between miscellaneous Ukrainian and foreign entities the Government decided to permit the JV "Elsacom Ukraine" to manage the "Globalstar" satellite system in Ukraine. Legal consequences of this decision were mirrored in the changes of Article 11 of the Law "On Communications" of 1995. The core of these changes was permission for non-governmental entities to have access to and to use communications networks if they "have a gateway on the Ukrainian territory and develop its satellite constellation with the use of Ukrainian launch-vehicles." ${ }^{2}$

After these changes were implemented, the "Globalstar" service provider could start its operations, since the conditions of its activities now completely corresponded to the Law's requirements. So JV "Elsacom Ukraine" started to build one of its gateways on the territory of Ukraine and "Globalstar" was developing its satellite constellation with the use of Ukrainian "Zenit" launch-vehicles.

For execution of the launch contract with "Globalstar" the Ukraine was looking for performance of the launches from the Baikonur Cosmodrome. In the light of this, a further legal problem appeared. Baikonur is located on Kazakh territory, but since 1994 has been leased by the Russian Federation. In dealing with the issues of the "launching state" and the liable party, the Parties to the Lease Agreement have agreed to follow the Liability Convention's provisions. In particular:

(1) In the case of damage ococuring when the Russian Federation undertakes activities from Baikonur, this country will bear the consequences of liability as if it were the sole launching state. The Republic of Kazakhstan will be considered neither as launch participant nor as launching state by the Russian Federation for the purpose of sharing the consequences of liability.

\footnotetext{
${ }^{2}$ Another, new version of this article was approved by the Parliament in 2000.
} 
(2) In the case of Russian-Kazakh joint space activities, Article V of the Liability Convention will apply.

(3) If the Russian Federation performs a joint activity with other countries, these countries will be jointly liable with the Russian Federation.

In the framework of the "Globalstar" satellites launch, the Ukraine requested, and received, permission from the Russian Government to take over all the obligations of the launching state under the Liability Convention. But of course the Ukraine and Russia can never agree between themselves to abrogate Liability Convention provisions vis-à-vis third parties. In all cases of Baikonour launches, at a minimum Kazakhstan (since it is Kazakh territory) and Russia (since it is a Russian facility and Russia would also be the state "which launches") qualify as the "launching states;" if in addition e.g. the Ukraine would become a state "which procures" a launch, then it would be a third liable state. The three can only agree amongst themselves to deal with the consequences of any international claim, e.g. provide that Russia will have to reimburse the Ukraine or Kazakhstan if either of these two is forced under the Liability Convention to pay a claim, or agreements of a similar nature. Therefore, the Lease Agreement and the existing practice of launches from the Baikonur are completely lawful from an international space law point of view.

For defining the launch's procedural matters, specific to the launch of the "Globalstar" satellites, in particular on aspects of liability, in 1997 the Ukrainian Government signed an Agreement with the Government of Kazakhstan on cooperation in the field of peaceful exploration and use of outer space. Also, in 1997 a special agreement was signed with Kazakhstan in which the places and conditions of landing of "Zenit" or separated parts thereof were defined.

As we can see, law-making is an important part of Ukrainian state policy, aimed at the development of its own space industry by expanding international cooperation.In the framework of such law-making activity some of the existing national regulations are changed, and a number of international agreements are concluded.

\section{Legal regulation of commercial space activities in Ukraine}

The above analysis permits us to conclude that all necessary preconditions have been established for the participation of Ukrainian space entities in international space projects. This has become possible because of the implementation of international obligations and the proper modification of existing national regulations.

National non-commercial space activities are also regulated in quite a satisfactory manner. Thanks to effective legal regulation the Ukraine has been successful in the development of the space potential which it inherited from the U.S.S.R.. In the field of national space activities the Ukrainian Government has wisely combined a regime of state regulation with the demands of the market economy. The national space law established is favorable for the space industry's day-to-day operations and its needs.

However, in the light of the growth both of the Ukrainian space industry and of the interest on the part of potential investors, it is important to understand the legal preconditions for carrying out commercial space activities in the territory of Ukraine.

The fundamentals for commercial space activities in Ukraine are still being developed. Until recent times, the state had not even addressed the challenge of developing detailed further regulations related to commercial space activities. A number of factors may explain this. First, most of the Ukrainian space companies are state-owned. According to the Law, most of the developed space companies cannot be privatized at all. Second, potential Ukrainian participants in the space market have not yet prepared themselves for active commercial ventures because of organizational and financial obstacles. Third, until recent times the state's prime attention was concentrated on preservation and stabilization of the space industry. The stage of further development has been initiated only recently. And finally, over the past few years, most of the commercial space projects with involvement of the Ukraine have taken place at the international level, outside the jurisdiction of Ukrainian law.

We can consider the signature by the President on February 6, 2001 of Decree No. 73/2001 “On Measures for Space Technologies Use for Innovative Development of State" as the first step towards the establishment of a legal framework for commercial space activities. The Conception of Space Industry Structural Reorganization and Innovative Development has been enforced by this Presidential Decree.

As was defined by the Conception, the main purpose of the space industry's structural reorganization is the development of an economically profitable industry, which would be capable of producing competitive products under market economy conditions. It is important to note that the principle of "commercial development of space activities, simultaneous application of market mechanisms and state regulations" is defined as the prevailing principle. Apparently, the adoption of new regulations will be required for realization of the Conception. These regulations will extend the regulatory basis for commercial space activities.

When analyzing the legal regime applicable to commercial space activities, it is important to review the status of the national subjects of space activities. The Law 
of 1996 defines as the subjects of national space activities: enterprises, institutions and organizations, including international and foreign. The form of ownership is not indicated by this definition. This allows us to assume that, in general, entities with different forms of ownership are entitled to participate in Ukrainian space activities.

This assumption is further supported by Article 4 of the Law "On Entrepreneurial Activities" of 1991, which provides the list of activities requiring a licence. Space activities are among others on this list. Moreover, the Law "On Licensing of Certain Types of Commercial Activities" of 2000 also includes space activities among the activities that require a licence (Article 9). Therefore, we can conclude that, if space activities can become the subject of entrepreneurial and commercial activities, this implies possible participation of entities with different forms of ownership.

As far as the legal regime for commercial space activities in a more comprehensive manner is concerned, regulations not only from national space law but also from other branches of Ukrainian law could apply. We do not intend to review the Ukrainian non-space law that could be applied to commercial space activity regulation. But it is important to mention that, unfortunately, in contrast to space law, Ukrainian commercial, investment, and customs laws have not been worked out properly enough for use in the regulation of commercial space companies and their operations. Also, the judicial system for space-related disputes settlement is still under development.

Nevertheless, significant progress has been made throughout recently. For instance, the new Law on the protection of intellectual property rights will be approved by the Parliament soon. It is expected that this Law will completely correspond to the applicable international, world-wide standards. Also, structural reforms are being implemented with regard to the judicial system. Active steps have been taken by the government in the field of protecting investors' interests.

Although space legislation has been worked out to a greater extent, its regulations still suffer from some imperfections. For example, in space insurance regulation a paradoxical situation has existed for a long time. The Law of 1996 has an Article, which is dedicated to the issue of space insurance (Article 24). This Article establishes that Ukrainian laws must define a list of types and procedures for space insurance. However, no corresponding additions were inserted into the Law "On Insurance" and other regulations. This situation changed only in the beginning of October of 2001, when the Parliament finally adopted the corresponding additions to the Law "On Insurance" of 1996.

We can also point out that neither specific regulations nor even declarations related to protection of in- tellectual property rights, disputes settlement procedures, and other institutions necessary for commercial space activities are inserted into the current Ukrainian space law. Accordingly, further regulatory development of Ukrainian commercial space activities is therefore needed.

\section{The Ukraine and the international security system}

The Ukraine is an important actor within the international security system because of its possession of missile technologies. When analyzing Ukrainian space legislation it is necessary to pay attention to those regulations related to protection of space technologies which could be used for military purposes.

Some years ago many discussions centred around the intention of some states (the Russian Federation, Ukraine, U.S.A.) to develop commercial launch vehicles based on military intercontinental missiles.

Missile technologies conversion has a complicated impact upon both the level and the methods of international security maintenance. Commercial development of "conversion" rockets involves not only purely technical matters, but also complicated legal problems [7].

As far back as the end of the 1950s, the Design Office "Yuzhnoye" started the development of new launch vehicles using military missiles as the first stages. So the launch vehicle SL-7 "Cosmos" was developed from the SS-4 missile, and the famous launch vehicle "Cyclone" from the SS-9 missile.

But most prominent from the commercial perspective is the conversion of the intercontinental ballistic missile SS-18. At the present time this missile has been developed into a commercial launch vehicle called "Dnepr." For this purpose the joint venture "Cosmotras" was established between the Russian Federation and the Ukraine. Some commercial payloads have already been successfully placed into orbit by 'Dnepr.'

The legal basis for the conversion of the SS-18 is the Treaty Between the United States of America and The Union of Soviet Socialist Republics on the Reduction and Limitation of Strategic Offensive Arms (STARTI Treaty). The subject matter of the Treaty concerns the reduction of strategic nuclear arms $(36 \%$ of carriers and $42 \%$ of cartridges). A total ban on the production and development of some missile arms' types is also provisioned. The Ukraine is a Party to the Treaty in accordance with the Lisbon protocol. In accordance with the Joint statement No. 21 signed in 1995 in Geneva, the Parties agreed to use the parts of military missiles for peaceful purposes.

The recent U.S. National Missile Defense (NMD) initiative, however, triggered much discussion in this respect. In this regard, it is useful to understand the 
Ukrainian position from the legal point of view. First, the Ukraine is a Party to the corresponding basic international treaties concluded under the auspices of the United Nations. Also, as mentioned above, the Ukraine is a Party to the START-1 Treaty and it is further a Party to the Agreement between States-participants of the Commonwealth of Independent States "On Warning Facilities for Missile Attack Prevention and Outer Space Control" of 1992. The Parties to this Agreement have agreed to co-operate in the exploitation and military management of warning facilities. This means that to a certain extent the Ukraine is part of the common missile defence system of the CIS. In 1997, the Ukraine had signed a bilateral agreement with the Russian Federation on the same subject as in the framework of the CIS (see above). In this Agreement, the Parties specified even more comprehensive procedures for mutual cooperation in the field of operation, maintenance and military management of warning facilities.

Space technologies are of great benefit to states. But unfortunately they often present the danger of being capable of use for military purposes. For instance, they could be used to deliver weapons of mass destruction. Therefore, the states-owners of space technologies are not only important actors in the international security system. They are also responsible for preserving space technologies for peaceful use.

\section{Final remarks}

What can we deduce from our analysis of Ukrainian space legislation? Within the Ukraine effective and extended national space legislation has been established in the relatively short period of 7 years. The general implications following from relevant international space law obligations-acceptance of, and dealing with state responsibility and liability for instance-were implemented in as thorough a fashion as the current status of international space law itself would allow for. For example, the application of the licensing obligation is applied widely to all those either operating within the Ukraine or otherwise falling under Ukrainian jurisdiction, as long as they undertake space activities. Also, the international legal regime pertaining to the military uses of outer space has been faithfully implemented at the national level.

Moreover, it is important to note that established legal and organizational conditions will help to further a successful law-making process. It is necessary to underline that in many respects the success of Ukrainian space activities depended on effective legal regulation. While more needs to be done, in particular in respect of private entities and the conditions under which they could be licensed, the essential framework is therefore in place, and a national space agency is readily available to undertake the main activities involved in such a licensing process.

We can note that if a state is really interested in developing its own space capabilities, it will take all possible steps for this purpose. And it will be particularly active in the field of law making, both international and national.

In the current situation, where international lawmakers are actively searching for new ways to enhance the effectiveness and applicability of international space law, the existence of effective national space legislation is especially important. In the future, it will be feasible to improve international space law by analyzing the various practices of application of national space laws.

As the modern Russian researcher A. Yakovenko has rightly pointed out, the "internal legislation of each country, to the extent touching upon a subject of exploration and use of outer space, must assist in strengthening international law and order" [8]. It is hoped that the Ukrainian national space law as briefly discussed above may be widely perceived as contributing exactly to those aims.

\section{References}

[1] Kolosov, Y., Zhukov, G., editors. International Space Law: the Textbook. Moscow: International Relations Publishing House, 1999. p. 13 (in Russian).

[2] Cheng, B. Studies in International Space Law. Oxford: Clarendon Press, 1997. p. 1xi. [3] Space Legislation of The Ukraine: Collected National Laws and Regulations and International Agreements. Kiev: Yurinkom Inter, 2001 (in Ukrainian with some texts in Russian).

[4] Gaverodskiy, A. Implementation of Regulations of International Law. Kiev: Vischa Shcola, 1980. p. 221 (in Russian).

[5] Available in French translation at http://fraise.univ-brest. $\mathrm{fr} / \sim$ kerrest/IDEI/Lois Nationales liste.html

[6] Yakovenko, A. The Modern Space Projects: International Legal Problems. Moscow: International Relations Publishing House, 2000. p. 76-77 (in Russian).

[7] Zhuravin, Y. Legal aspects of launches of conversion rockets. News of Cosmonautics 1999; 3(194): 52.

[8] Yakovenko, A. The Modern Space Projects: International Legal Problems. Moscow: International Relations Publishing House, 2000. p. 95. 